\title{
Enemy of All Humanity
}

\section{The Dehumanizing Effects of a Dangerous Concept}

\author{
Marc de Wilde
}

\section{Introduction}

David Luban has written a fascinating paper on the concept of the hostis humani generis, the 'enemy of all humanity. ${ }^{1}$ He traces this concept back to Cicero, who argued that 'a pirate is not included in the number of lawful enemies, but is the common enemy of all [communis hostis omnium].' ${ }^{2}$ As Luban explains, Cicero's concept would have a remarkable career in legal history, being applied not only to pirates, but to all kinds of villains, including professional poisoners, assassins, incendiaries, tyrants, ruthless aggressors, and slave traders. In our own time, perpetrators of international core crimes such as torturers and génocidaires have been identified as 'enemies of all humanity.' Therefore, Luban believes that the 'enemy of all humanity' is still a useful and indispensable legal concept, especially in the field of international criminal law. He claims that no other concept 'quite captures the twin nature of atrocity and persecution crimes that makes the idea of international criminal justice imperative, that they are radically evil, and that they are everyone's business.' ${ }^{3}$ Although Luban is aware that this concept has been abused in the past to deprive 'enemies of all humanity' of their rights, he also believes that the 'modern motivation to use the label hostis humani generis has been to put radical evil on trial, not to preclude such trials.' ${ }^{4}$ Thus, so long as we insist that 'enemies of all humanity' are themselves members of humanity and accountable to humanity, there is no danger that they will be dehumanized or deprived of their rights. ${ }^{5}$

It is here that I would like to take issue with Luban's interpretation, notwithstanding the wealth of insights he provides. My impression is that ultimately Luban underestimates the risks inherent to the 'enemy of all humanity' concept. Contrary to Luban, I believe that, even if the concept is used with the intention to hold today's 'enemies of all humanity' legally accountable, it risks having the

1 David Luban, 'The Enemy of All Humanity,' Netherlands Journal of Legal Philosophy 2 (2018): 112-137.

2 Cicero, On Duties, trans. Walter Miller (Cambridge, MA: Harvard University Press, 1913), 3.29.107.

3 Luban, 'Enemy of All Humanity,' 134.

4 Luban, 'Enemy of All Humanity,' 133.

5 Luban, 'Enemy of All Humanity,' 136. 
opposite effect of undermining, rather than preserving, the rule of law. ${ }^{6}$ More particularly, as I intend to show in this paper, in the past, the concept has often served to justify the establishment of parallel systems of justice, one reserved for ordinary criminals and the other for 'enemies of all humanity,' who were simultaneously deprived of their rights as suspects under criminal law and as 'lawful enemies' under the laws of war. ${ }^{7}$ Hence, I believe that the 'enemy of all humanity' is an inherently dangerous concept: its main effect is that 'enemies of all humanity' are placed outside the normal legal order and deprived of legal protection. Moreover, my impression is that modern international criminal justice does not need the concept of the 'enemy of all humanity.' As Luban himself notes, 'surprisingly, the literal phrase hostis generis humani almost never appears in the case-law of international tribunals. ${ }^{8}$ However, this may not be so surprising, as international tribunals can easily do without the phrase: they can hold perpetrators of international core crimes legally accountable without denouncing them as 'enemies of all humanity.'

To support his attempt to revive the 'enemy of all humanity' concept in international criminal law, Luban proposes an alternative genealogy of the concept, tracing it back to ancient tyrants, instead of pirates. He observes that, unlike Cicero's pirates, today's 'enemies of all humanity' tend to be state officials, who abuse state power to commit atrocity and persecution crimes. He concludes that the modern hostis humani generis, who foments hatred on racial, ethnic or religious grounds, 'shares far more DNA with the ancient tyrant than with the ancient pirate, and his misdeeds are more likely offenses committed by and through states than committed against states. ${ }^{9}$ Although Luban is right to emphasize that 'genealogy is indispensable to philosophy,' 10 my impression is that the alternative genealogy he proposes is dictated by philosophical, rather than historical considerations. In the past, the 'enemy of all humanity' concept has indeed been applied

6 Here, I agree with Antony Duff that the 'enemy of all humanity' is a dangerous concept that should be expunged from the courtroom, albeit perhaps for different reasons. It is thus not inconsistent to put 'enemies of all humanity' on trial, but doing so inevitably disrupts the rule of law, which is aimed at excluding particular offenses, not the actors who committed them. Antony Duff, 'Authority and Responsibility in International Criminal Law,' in The Philosophy of International Law, eds. Samantha Besson and John Tasioulas (Oxford: Oxford University Press, 2010), 602-4.

7 In developing this argument, I was inspired by Dan Edelstein's The Terror of Natural Right: Republicanism, the Cult of Nature, and the French Revolution (Chicago: Chicago University Press, 2009). Edelstein shows how during the French Revolution, the Montagnards' use of the 'enemy of all humanity' concept eventually led to a parallel system of justice, in which suspected counterrevolutionaries were tried as transgressors of the laws of nature. I have also profited much from Daniel Heller-Roazen's The Enemy of All: Piracy and the Law of Nations (New York: Zone Books, 2009), which traces the 'enemy of all humanity' concept from Cicero's pirates to present-day terrorists. Like Edelstein, Heller-Roazen is highly critical of how the concept has been used to dehumanize these 'enemies of all humanity' and deprive them of their rights.

8 Luban, 'Enemy of All Humanity,' 126.

9 Luban, 'Enemy of All Humanity,' 130.

10 Luban, 'Enemy of All Humanity,' 113. 
to tyrants - especially in the early-modern natural law tradition ${ }^{11}$ - yet it has also been applied against their political opponents, and with far more deadly consequences. It is this ambiguity of the concept - that, depending on the political context in which it is used, it can be directed against tyrants or against their opponents - which, it seems to me, Luban has not sufficiently acknowledged.

\section{Back to Rome: using the pirate analogy to outlaw political opponents}

As Luban explains in his paper, the 'enemy of all humanity' concept has its roots in ancient Rome. In his On Duties, Cicero introduces the concept of a 'common enemy of all' (without referring to 'humanity') in the context of a discussion of the duties of 'good faith [fides]' and promise-keeping: he argues that promises made to an enemy must be kept, especially if they are supported by an oath. ${ }^{12}$ This implies that if a Roman general has promised to the enemy that he will abide by the terms of a peace treaty, he is bound by his promise. By contrast, if he breaks his promise and violates the treaty, he ought to be punished as a perjurer. ${ }^{13}$ According to Cicero, there is, however, one exception to this rule: promises made to pirates are not binding. If one violates such promises, one does not commit perjury. As Cicero explains, 'suppose that one does not deliver the amount agreed upon with pirates as the price of one's life, that would be accounted no deception - not even if one should fail to deliver the ransom after having sworn to do so; for a pirate is not included in the number of lawful enemies, but is the common enemy of all [pirata non est ex perduellium numero definitus, sed communis hostis omnium]; and with him there ought not to be any pledged word nor any oath mutually binding. ${ }^{14}$ In other words: because pirates are not included among our lawful enemies, the promises made to them are not binding, even if they are supported by an oath, and if one violates such promises, one does not commit perjury. Instead, in dealing with pirates, we may act like Caesar, who, in $81 \mathrm{BC}$, was captured by pirates off the coast of Lesbos, and after his release, instead of delivering the ransom he had vowed to pay, tracked them down and

11 For instance, in his Second Treatise of Government (1689), John Locke denounced any ruler who violated his trust by structurally transgressing the natural rights of his subjects as a 'declared Enemy to Society and Mankind' and the 'common Enemy and Pest of Mankind.' John Locke, 'Second Treatise of Government,' in Two Treatises of Government, ed. Peter Laslett (Cambridge: Cambridge University Press, 2005), §93 and §230.

12 Cicero, On Duties, 3.29.107.

13 Cicero explains that Roman generals who had violated an oath sworn before a lawful enemy were punished by being delivered 'into the good faith and power' of the enemy. Ibid., 3.29.108. On the legal sanctions for violations of fides, see: Dieter Nörr, Die Fides im römischen Völkerrecht (Heidelberg: Müller, 1991), 7-8 and my 'Fides Publica in Ancient Rome and its Reception by Grotius and Locke,' Legal History Review 79 (2011), 455-87.

Cicero, On Duties, 3.29.107-108 (trans. modified). 
had them crucified without legal formalities - an act for which he was widely admired, rather than condemned as a perjurer. ${ }^{15}$

For Cicero, the distinction between lawful and unlawful enemies is decisive: while Roman officials are bound by the laws of war with regard to a 'just and legitimate enemy [hostis iustus et legitimus], ${ }^{16}$ they do not have such legal obligations towards unlawful enemies, such as pirates, who attack their ships and raid their shores without distinction or warning. According to Cicero, these unlawful enemies are neither protected by the law of citizens (ius civile), nor by the law of nations (ius gentium). They fall outside the sphere of Roman legal obligations and outside the sphere of mutual trust which governs relations with lawful enemies. As Daniel Heller-Roazen explains,

'the crucial distinction lies in the acceptance or rejection of the principle that, for Cicero, founds legality and justice (iustitia) in general: "good faith, that is, constancy and fidelity to what is said and agreed" (fides, id est dictorum conventorumque constantia et veritas). This would clearly explain why it is that to the lawful enemy a promise must be kept. Even he, while hostile, acts in good faith; despite aggression, he still seeks to do that which he has sworn to do by the law of duty ... Not so the pirate, nothing ought to be owed to him because he lives without such "good faith", 17

The fact that promises made to pirates are not binding indicates the very radical manner in which pirates are excluded from the law: they are excluded from the obligations of fides, of 'good faith,' which Cicero regards as the ultimate source of justice and legality. While it is possible to conclude peace treaties with lawful enemies (who are bound by 'good faith'), it is impossible to make binding agreements with pirates, since they are not led by the law of duty or 'good faith.' For this reason, Heller-Roazen concludes that nothing can be owed to a pirate, whether morally or legally, because he 'lives without such "good faith".'

As Luban observes, Heller-Roazen's reading may support a connection between ancient pirates and modern terrorists, who have been classified as 'unlawful enemy combatants' by the Bush administration and simultaneously deprived of their rights as suspects under criminal law and lawful combatants under the laws of war. However, Luban 'doubts that Cicero's language can support conclusions about lawful and unlawful combatants. ${ }^{18}$ Explaining Cicero's remark that a pirate is an 'enemy [hostis],' but not a 'lawful enemy [perduellis],' Luban observes that there is 'no indication that hostis denotes an unlawful combatant while a perduel-

Velleius Paterculus, Roman History, 2.42.3, Suetonius, Life of Caesar, 4.1-2, Plutarch, Life of Caesar, 1-2, Valerius Maximus, Memorable Doings and Sayings, 6.9.15. See for a discussion of these and other sources: Allen M. Ward, 'Caesar and the Pirates,' Classical Philology 70, no. 4 (1975), 267-68. According to Plutarch's account, Caesar had the pirates crucified - a punishment usually imposed on slaves.

16 Cicero, On Duties, 3.29.108.

17 Heller-Roazen, Enemy of All, 17.

18 Luban, 'Enemy of All Humanity,' 116. 
lis is a lawful combatant.' ${ }^{19}$ In this context, Luban refers to two second-century legal sources from Justinian's Digest, in which a distinction is made between lawful enemies (hostes) and unlawful ones, such as 'robbers [latrunculi]' and 'bandits [praedones]. ${ }^{20}$ For Luban, this shows that when Cicero uses the term hostis to define pirates, his word-choice is 'colloquial, not technical': the term 'hostis' can refer to both lawful and unlawful enemies, and therefore, Cicero's designation of pirates as hostes does not in itself imply that they are beyond the pale of the law. ${ }^{21}$ However, according to Luban, there is an important difference between pirates and land-based bandits and robbers: 'while the robber on land challenges one state's authority - the territorial state's - the pirate challenges all states' authority, because he attacks all states' shipping and seacoasts. ${ }^{22}$ According to Luban, it is for this reason that Cicero defines the pirate as the 'common enemy of all,' for, unlike land-based bandits and robbers, it is characteristic of the pirate that he 'disrespects state authority as such;' he commits a 'generalized lèsemajesté,' a 'kind of blasphemy against the order of rulers' and an 'insult to state authority as such, manifest in the pirate's way of life. ${ }^{23}$ Luban concludes that this makes the pirate the 'common enemy of all states - but not necessarily of all people. ${ }^{24}$

Although Luban's interpretation resonates with the way in which Cicero would be read by later generations, it does not fit well with the historical context in which he was writing, when the pirates that were prowling around in the Mediterranean were surrounded not by states, but by Roman provinces, and an abstract concept of the state (as distinguished from its people) did not yet exist. ${ }^{25}$ Moreover, the legal sources of the Digest do not support the categorical distinction between land-based bandits and pirates that Luban proposes: instead, both seem to fall in the same category of unlawful enemies to whom neither legal obligations, nor obligations of 'good faith' are owed. ${ }^{26}$ However, more importantly, elsewhere in his writings, Cicero himself defines the pirate as the 'common enemy of all peo-

, 'Enemy of All Humanity,' 116. captured by bandits, one does not become the slave of those bandits. However, if one is captured by a lawful enemy, one does become their slave and one needs the right of postliminium to regain one's citizenship status.

21 Luban, 'Enemy of All Humanity,' 116.

22 Luban, 'Enemy of All Humanity,' 118.

23 Luban, 'Enemy of All Humanity,' 118.

24 Luban, 'Enemy of All Humanity,' 119 (my italics).

25 As Wolfgang Kunkel explains, 'the Romans never thought of the state in the abstract way we do today. It was not for them an impersonal power standing in opposition to the individual, whose actions were dependent on its permission, but rather the individuals themselves - that is, the citizens - collectively.' Wolfgang Kunkel, An Introduction to Roman Legal and Constitutional History (Oxford: Oxford University Press, 1966), 9. On the Roman concept of the state: Richard Klein, Das Staatsdenken der Römer (Darmstadt: Wissenschaftliche Buchgesellschaft, 1966) and Ernst Meyer, Römischer Staat und Staatsgedanke (Zurich: Artemis-Verlag, 1975). aut latronibus]' cannot legally enslave their prisoners. 
ples and nations'27 - a passage that is not mentioned by Luban. The context is Cicero's second oration against Verres, the former governor of Sicily, who, in 70 $\mathrm{BC}$, was tried for abusing his office and enriching himself at the expense of the Sicilian population. At his trial, Cicero accused the former governor of having offered a refuge to pirates. More particularly, he claimed that Verres had removed for his own purpose a number of pirates from their captured vessels and, instead of having them publically executed, had included them as slaves into his household. Addressing Verres at his trial, Cicero asks: 'What right, or custom, or precedent for such behavior can you allege? This cruel and deadly enemy of the Roman nation - let me rather say, this common enemy of all nations and peoples [communem hostem gentium nationumque omnium] - shall any private person in all the world be allowed to keep him living inside the walls of his own house?' ${ }^{28}$ What should be noted is that, first of all, Cicero emphasizes that the pirate is the common enemy, not only of the Romans, but of all nations. Moreover, contrary to Luban's interpretation, Cicero does not seem to regard the pirate as an enemy of states, but as an enemy of nations and peoples.

However, most importantly, in this context, the term 'enemy of all' seems to be directed, not primarily against the pirates themselves, but against the former governor who is accused of aiding pirates. Cicero emphasizes that, by protecting pirates, Verres had sacrificed the public safety to his own private interests, thereby violating the fides, the requirement of 'good faith. ${ }^{29}$ Elsewhere, he even suggests that Verres had himself become a 'bandit' and a 'pirate': 'He has played the bandit [praedo] himself: Verres, whose black deeds of piracy [pirata] we find done here in the heart of Rome. ${ }^{30}$ Cicero's use of the pirate-analogy can be understood against the background of the civil wars, when the term hostis was increasingly applied to Roman citizens. ${ }^{31}$ By declaring them hostis publicus, or 'public enemy,' they were deprived of legal protection, such that they could be killed by anyone with impunity. When Cicero became a consul in 63 BC, he was himself authorized by the senate to declare Catiline and his associates 'public enemies' and had several of them executed without a trial - a decision for which he was later severely criticized (and eventually exiled). ${ }^{32}$ Read against this background, Cicero's definition of the pirate as a communis hostis omnium acquires a different, and darker, connotation: it connotes that some enemies may be killed with impunity, as they are no longer protected by the laws for citizens or the laws of war. In this context, it can also be understood why Cicero denounces Verres, Cati-

27 Cicero, Against Verres II, 5.30.76.

28 Cicero, Against Verres II, 5.30.76.

29 Cicero, Against Verres II, 5.30.77.

30 Cicero, Against Verres II, 1.59.154 (trans. modified). Cf. Cicero, Against Verres II, 2.75.184 and 4.47.104. On Cicero's depiction of Verres as a pirate, see Philip de Souza, Piracy in the GraecoRoman World (Cambridge: Cambridge University Press, 1999), 152-53.

31 P. Jal, 'Hostis (publicus) dans la littérature latine de la fin de la république,' Revue des études anciennes 65 (1963): 53-54.

32 Jürgen von Ungern-Sternberg, 'Das Verfahren gegen die Catilinarier oder: Der vermiedene Prozess,' in Grosse Prozesse der römischen Antike, eds. Ulrich Manthe and Jürgen von Ungern-Sternberg, (Munich: Beck, 1997), 98-9. 
lina and Mark Antony as 'bandits' and 'pirates,' that is, as unlawful enemies, to whom no legal obligations or obligations of good faith are owed. ${ }^{33}$ In his Philipics, he even repeatedly and explicitly calls Antony a hostis omnium, an 'enemy of all.'34 Here, the language used for outlawing pirates - or, to put it in modern terms, for justifying irregular and asymmetrical warfare against them - is applied against a Roman politician, who is denounced as an 'enemy of all,' and declared beyond the pale of the law. It is this aspect of the hostis omnium label that Luban fails to notice: that it was used, not only to define pirates, but also to deprive Roman citizens of their rights, leaving them without any legal protection whatsoever. As we will see below, the use of the 'enemy of all humanity' concept to outlaw political opponents would be repeated several times in history, with increasingly deadly consequences.

\section{Reincarnations: pirates, rebels and savages}

After the fall of the Roman empire, Cicero's concept of the communis hostis omnium was preserved in Christian theology, but instead of the pirate, it was the devil who was identified as the 'common enemy of all.'35 Gregory the Great (d. 604) characterized the devil as the antiquus hostis humani generis, 'the ancient enemy of all humanity. ${ }^{36}$ Gregory's expression became a widespread designation for the devil in the medieval period; it could be found in demonology treatises and was eventually even included in the Church's official exorcism ritual. ${ }^{37}$ In the twelfth century, the glossators, jurists teaching at the university of Bologna, rediscovered Justinian's Digest and with it the opinions of Roman jurists on piracy and banditry. Commenting on these texts, Azo and his pupils Odofredus and Accursius distinguished lawful enemies from mere bands of 'brigands [latrones]' and 'robbers [latrunculi],' explaining that the latter were excluded from

33 See, for instance, Cicero, Against Catiline, 1.10.27: 'I achieved this much when I kept you [Catiline, MdW] from the consulship, that you would only be able to attack the State as an exile and not harry it as a consul and that this criminal attack upon which you have embarked, would go under the name of banditry not war [latrocinium potius quam bellum nominaretur].' See also Cicero, Philipics, 4.14-15: 'what reckoning can there be with a man [Antony, MdW] whose cruelty is incredible and whose good faith [fides] is non-existent? The whole conflict lies between the Roman people, the conqueror of all nations, and an assassin, a bandit [latrine], a Spartacus.' And Cicero, Against Verres, II, 4.1.1: 'I come now to what he [Verres, MdW] speaks of as his favourite pursuit, his friends as a foolish weakness, Sicily as highway robbery [latrocinium].'

34 Cicero, Philipics, 10.21 and 13.5. On Cicero's depiction of Antony as an 'enemy of all,' see: See also Harry D. Gould, 'Cicero's Ghost: Rethinking the Social Construction of Piracy,' in Maritime Piracy and the Construction of Governance, eds. Michael J. Struett, John D. Carlson and Mark T. Nance (New York: Routledge, 2013), 26.

35 Edelstein, Terror, 30; Gould, 'Cicero's Ghost,' 30.

36 Santi Gregorii magni Romani pontificis moralium libri, 6.3.7, in Patrologia Latina, ed. Migne, vol. 76. I gratefully take this reference from Edelstein, Terror, 31.

37 Edelstein, Terror, 31. Edelstein quotes a later formulation from the Rituale Romanum, reproduced in Manuel d'excorcismes de l'église (Charenton: G.V.P., 2000 [1626)], 47: 'hear then and obey, Satan, attacker of the faith, enemy of all humanity [inimice fidei, hostis humani generis].' 
the privileges of war. ${ }^{38}$ Their successors in Bologna, the fourteenth-century commentators Bartolus de Saxoferrato and Baldus de Ubaldis explained that 'pirates are considered equal to enemies of faith and of the Prince [hostibus fidei \& Principis], and they can be dispossessed by anyone with impunity, for they are forfeited by the law itself. ${ }^{39}$ It was through these medieval readings of Roman legal sources that the concept of an 'enemy of all humanity' entered the early-modern treatises on the law of nature and nations.

In his pioneering Treatise on Military Matters and Warfare (1563), Pierino Belli explained that hostilities should not be begun except after war had been publically declared. ${ }^{40}$ However, invoking Baldus, he observed that, under customary law, an exception was made in the case of pirates, for 'they are both technically and in fact already at war; for people whose hand is against every man should expect a like return from all men, and it should be permissible for any-one to attack them.' ${ }^{41}$ Aware of Cicero's use of the pirate-analogy in the context of civil war, Belli compared pirates and bandits to 'public enemies,' claiming that they were 'outside the pale of the laws' and could be killed with impunity by anyone: 'even persons in private life may assault such outlaws - and to the point of killing them. ${ }^{42}$ In a similar vein, Balthazar de Ayala, a Spanish jurist writing at the time of the Dutch revolt (1582), compared 'rebels' to pirates and robbers, arguing that they lacked the privileges of war. Emphasizing the asymmetry of warfare against these unlawful enemies, Ayala maintained that 'all the modes of stress known to the laws of war may be employed against them, even more than in the case of enemies, for the rebel and the robber [rebellis et latro] merit severer reprobation than an enemy who is carrying on a regular and just war [legitimus et iustus hostis] and their condition ought not to be better than this. ${ }^{43}$ By placing rebels in the same category as pirates and robbers, Ayala expressed the political convictions of his time: in 1580, King Philip II of Spain had proscribed the leader of the Dutch revolt, Prince William of Orange, as a 'rebel' and an 'enemy of all humanity [vyandt des menschelicken geslachtes],' implying that he was not protected by the laws of war. ${ }^{44}$

38 Heller-Roazen, Enemy of All, 103.

39 Bartolus de Sassoferrato, 'De captivis et postliminio reversis rubrica,' in Lucernae iuris omnia quae extant opera, tomus sextus: commentaria digesti novi partem (Venice, 1596), fol. 215. See also Baldus de Ubaldis, 'De furtis et servo corrupto rubrica,' in In sextum codicis librum commentaria (Venice, 1599), fol. $14 \mathrm{v}$.

40 Pierino Belli, A Treatise on Military Matters and Warfare in Eleven Parts, trans. Herbert C. Nutting (Oxford: Clarendon Press, 1936 [1563]), vol.2, 2.11.1-2 (83).

41 Belli, Treatise on Military Matters, 2.11.1-2 (83). Harry Gould recognizes in these passages a prefiguration of the modern idea that pirates might fall under universal jurisdiction. However, Belli primarily refers to the immunity granted to anyone who killed a pirate. Goud, 'Cicero's Ghost,' 30.

42 Belli, Treatise on Military Matters, 2.11.2 (83).

43 Balthazar de Ayala, Three Books on the Law of War and on the Duties Connected with War and on Military Discipline, trans. John Pawley Bate (Washington: Carnegie Institution, 1912 [1582]), 1.2.15 (11-2).

44 The Apologie or Defence of the Most Noble Prince William, by the grace of God, Prince of Orange, etc. (Delft, 1581), B. 4 (fol. 4r.). 
Like Belli and Ayala, Alberico Gentili, an Italian Protestant teaching Roman law at Oxford, compared rebels to pirates and robbers, explaining that they could not emancipate themselves from a state's jurisdiction by rebellion. ${ }^{45}$ As Gentili observed, the law of nations could be considered a pact of all nations: pirates, robbers and rebels had withdrawn from this pact and broken the 'treaty of all mankind [foedus humani generis].' Therefore, they could not enjoy the privileges of the law they rejected. The novelty of Gentili's interpretation was not that he declared pirates, robbers and rebels beyond the pale of the law (as we have seen, Belli and Ayala had done so before him), but the manner in which he explained their exclusion. ${ }^{46}$ According to Gentili, the reason why pirates, robbers and rebels were excluded from the privileges of war was that they lacked a 'public cause. ${ }^{47}$ As Alfred Rubin explains, Gentili's treatise marked a crucial step in the history of piracy: it not only provided a legal criterion for distinguishing pirates from lawful enemies, but also the key to transforming such unlawful combatants into legitimate state actors. The key to this miraculous transformation was the "license of an established sovereign: ${ }^{48}$ by grating a letter of marque, rulers could commission pirates and transform them into privateers, that is, lawful combatants with a 'public cause. 49 According to Gentili, it was by adopting a public cause that pirates could advance to the status of lawful combatants, who were protected by the laws of war, and it was only an established sovereign, who could provide such a public cause by recognizing them as lawful combatants fighting on his behalf.

However, Gentili's criterion for distinguishing lawful from unlawful combatants was rejected by Hugo Grotius, who believed that it could not depend on sovereign license. ${ }^{50}$ Instead, Grotius argued, it depended on the purpose for which these combatants had united: 'pirates and brigands are banded together for wrongdoing; the members of a state, even if at times they are not free from crimes, nevertheless have been united for the enjoyment of rights, and they do render justice to foreigners. ${ }^{51}$ For this reason, members of states were protected by the laws of war, while pirates and brigands were excluded from such legal protection. However, Grotius added, sometimes a 'transformation' occurred: bands of brigands and pirates could advance to forming a state of their own if they 'embrace[d] another mode of life. ${ }^{52}$ Crucially, they could not only be transformed into lawful combatants by sovereign license as Gentili had argued, but they could also transform themselves into lawful combatants by embracing 'another mode of life,' and,

Alberico Gentili, Three Books on the Law of War, trans. John C. Rolfe, introd. Coleman Phillipon (Oxford: Clarendon Press, 1933 [1589]), vol. 2, 1.4.34 (22).

Heller-Roazen, Enemy of All, 107.

Gentili, Law of War, 1.4 .39 (24).

Alfred P. Rubin, The Law of Piracy (Irvington-on-Hudson/ New York: Transnational Publishers, 1998), 29.

9 Rubin, Law of Piracy, 30; Heller-Roazen, Enemy of All, 108.

Hugo Grotius, On the Law of War and Peace, trans. Francis W. Kelsey (Oxford: Clarendon, 1925 [1625]), 3.3 (630-640). Heller-Roazen, Enemy of All, 110.

Grotius, Law of War and Peace, 3.3.2 (631).

Grotius, Law of War and Peace, 3.3 .3 (632-33). 
more specifically, by 'uniting themselves for the enjoyment of rights. ${ }^{53}$ Moreover, in sharp contrast to his predecessors, Grotius suggested that agreements made with pirates and brigands were legally binding. In a passage which is not discussed by Heller-Roazen (and which does not fit with his thesis of their radical exclusion), Grotius refuted Cicero's claim that 'good faith' ought not to be kept with pirates and brigands. Invoking historical examples, he pointed out that it was sometimes advantageous for states to come to terms with pirates and brigands, and to perform the promises made to them, for this proved the most effective way to end hostilities. ${ }^{54}$ However, Grotius also rejected Cicero's claim on principled grounds: although agreements with pirates and brigands were not be binding under the law of nations, they were binding under the law of nature: since their authors 'were human beings, they had a common share in the law of nature [quia homines sunt, communionem habent juris naturalis]. ${ }^{55}$

Grotius's claim that promises made to pirates and brigands were legally binding proved immensely controversial. His suggestion that even pirates should reap the advantages of good faith was considered particularly offensive. Thus, Samuel von Pufendorf defended Cicero against Grotius: 'Since a pirate is the common enemy of all, that is, a man who without having been injured robs and murders any person whomsoever that he meets, and therefore, on his own confession, disturbs, destroys that social relationship between men which has been instituted by God; he has, in consequence no right to avail himself of that bond, whereby men are accustomed to engage themselves to a social life, according to the command of God. And since his manner of life is an open profession of atheism, he should reap no advantage from religion. ${ }^{56}$ According to Pufendorf, pirates lived a life without faith, murdering and robbing anyone without distinction or cause, and destroying the social relationship between men which had been instituted by God. While Grotius had suggested that obligations of good faith were owed even to pirates, since 'a man is thereby bound not only to man but also to God,'57 Pufendorf believed that pirates, being faithless themselves, should not profit from the good faith of others. Their manner of life being an open profession of atheism, they should reap no advantages from religion, nor should they avail themselves of that social bond which they categorically rejected by attacking the

53 Here Grotius may have thought of the example of the so-called 'Sea-Beggars' of his native Holland, who, in the previous decades, had transformed themselves from 'rebels' and 'pirates' into the regular army of the newly established Dutch Republic. Cornelis de Meij, De watergeuzen en de Nederlanden, 1568-1572. Verhandelingen der Koninklijke Nederlandse Akademie van Wetenschappen, Afdeling Letterkunde (Amsterdam: Noord-Hollandsche Uitgevers Maatschappij, 1972), 77, no. 2, 100.

54 Among other historical examples, Grotius referred to Pompey, who, on Plutarch's account, had succeeded in ending the war with the Cilicean pirates by means of treaties, promising to spare their lives and to relocate them to places where they might live without plundering. Grotius, Law of War and Peace, 3.19.2.2. The reference is to Plutarch, The Life of Pompey, 27.

55 Grotius, Law of War and Peace, 3.19.2.2.

56 Samuel von Pufendorf, Eight Books on the Law of Nature and Nations, trans. C.H. Oldfather and W.A. Oldfather (Oxford: Clarendon Press, 1934 [1672, edition of 1688]), 4.2.8.

57 Grotius, Law of War and Peace, 3.19.5. 
shipping and seacoasts of all nations. Contrary to Grotius, Pufendorf concluded that agreements made with pirates were not binding: oaths sworn before pirates should not be kept, just as 'no prudent person places any confidence in the oaths of such men. ${ }^{58}$

Agreeing with Pufendorf, the German natural lawyer Christian Wolff wrote that he did 'not wish to repeat what [could] be read in Grotius.'59 On his opinion, 'nothing too harsh' could be said 'against those who plainly show that they are enemies of the whole human race [totius generis humani hostes]. ${ }^{60}$ According to Wolff, those who endangered the security of all nations by seeking war as an end in itself were equal to 'robbers whose malice extends to the farthest limit.' As Wolff explained, 'the right to punish them belongs to all nations, and by this right they can remove from their midst those fierce monsters of the human species [fera ista generis humani monstrae]. ${ }^{61}$ Adopting a similar dehumanizing language, the Swiss diplomat Emer de Vattel claimed that 'those who appear to relish the horrors of war, who wage it on all sides without reason or pretext, and even without other motive than their savage inclinations, are monsters, unworthy of the name of men [monstres, indignes du nom d'hommes].' ${ }^{62}$ Like Wolff, Vattel applied the 'enemy of all humanity' concept not only to pirates, but also to states that engaged in aggressive warfare, thereby endangering the security of all nations. According to Vattel, such states 'should be regarded as enemies of the human species [Ennemis du Genre-humain], just as in civil society persons who follow murder and arson as a profession commit a crime not only against the individuals who are victims of their lawlessness, but against the state of which they are the declared enemies.' He concluded that '[o]ther nations are justified in uniting together as a body with the object of punishing, and even of exterminating such savage peoples [même pour exterminer ces peuples féroces].'63

As Dan Edelstein has showed in his fascinating study on the Terror of Natural Right, the French revolutionaries drew on these natural law discourses to draft and authorize the laws underpinning the Terror. ${ }^{64}$ Inspired by these discourses, the Jacobins developed a theory of 'natural republicanism,' suggesting that the republic was founded directly on the laws of nature. This enabled them to accuse their opponents of 'crimes against nature,' denouncing them as 'unnatural beings,' who had conspired against the republic and thereby endangered the lib-

59 Christian Wolff, The Law of Nations Treated According to a Scientific Method, trans. Joseph H. Drake (Oxford: Clarendon Press, 1934 [edition of 1764]), 6.627.

60 Wolff, Law of Nations, 6.627.

61 Wolff, Law of Nations, 6.627. The phrase 'monster of the human race [humani generis monstrum]' can be found twice in these passages. See also: Heller-Roazen, Enemy of All, 116-177 and 218, n. 44.

62 Emer de Vattel, The Law of Nations, or the Principles of Natural Law Applied to the Conduct and to the Affairs of Nations and of Sovereigns, trans. Charles G. Fenwick (Washington, DC: Carnegie Institution, 1916 [after the edition of 1758]), 3.3.34.

Vattel, Law of Nations, 3.3.34.

Edelstein, Terror, 158-63. 
erty of all. As Edelstein explains, 'since the Jacobins equated the republic and its goals with nature itself, almost any potentially subversive activity could be prosecuted as a crime against nature. The exceptional became terrifyingly normal. ${ }^{65}$ More than any other aspect of their ideology, it was the 'enemy of all humanity' concept that facilitated the normalization of state violence during the Terror: as Edelstein points out, 'the hostis humani generis category lay at the heart of the Montagnard prosecution of the king, but subsequently provided a template for other categories of hostility, from the notorious hors-la-loi (outlaw) up to the "enemy of the people". 66 Once the Montagnards had claimed the exceptional authority to prosecute their king as an 'enemy of all humanity,' the exception ran the risk of becoming the rule, as it became conceivable to prosecute other 'counterrevolutionaries' as transgressors of the laws of nature. The Montagnards' discourse of absolute hostility thus gradually extended from the king to his supporters to anyone accused of subversive activities. ${ }^{67}$

By declaring their political opponents hors-la-loi, the Jacobins effectively 'rebranded' the hostis humani generis category. However, Edelstein suggests that, unlike the traditional 'enemy of all humanity,' those who were declared hors-la-loi during the Terror 'were not entirely beyond the law. ${ }^{68}$ Instead, they were 'hors-la-loi civile, that is, they were to be denied the protection and rights afforded by positive law (first and foremost, the right to a trial),' but they were not hors-la-loi naturelle. ${ }^{69}$ As Edelstein explains, the Jacobins' claim that they were tried according to natural law led to the creation of a 'parallel legal system': 'whoever violated the laws of nature deserve[d] swift execution with few (if any) legal forms. ${ }^{.70}$ Although Edelstein convincingly shows that the Jacobins used the discourse of natural law to establish a parallel system of justice, I believe it is also important to note the shift in their discourse from the 'enemy of all humanity [ennemi du genre humain]' to the 'enemy of the people [ennemi du peuple].' Those accused of attacking the 'unity, liberty and security of the Republic' (rather than the security of all nations), were designated 'enemies of the people' (rather than enemies of all humanity), and deprived of their rights. Moreover, although Edelstein is right to conclude that these 'enemies of the people' did not 'reside in an "anomic" zone,' it can be doubted whether the Jacobins' minimalist conception of natural justice gave them any legal protection at all: rather, by suspending virtually all proce- 
dural rules, ${ }^{71}$ they became completely dependent on the goodwill of their judges, who risked being themselves accused of obstructing the Jacobins' revolutionary aims if they delivered too little convictions. Thus, the parallel system of 'justice' set up by the Jacobins offered the accused barely any legal protection at all, but primarily seems to have served as a means to facilitate their swift and efficient execution.

\section{Back to the future: from 'enemy of the people' to 'enemy of all humanity'}

In the second edition of his Concept of the Political (1932), Carl Schmitt warned against the use of the 'enemy of all humanity' concept. He explained that wars waged in the name of humanity had an 'especially intensive political meaning': as Schmitt observed, it was not 'humanity' that waged these wars, but particular states that sought to delegitimize their political opponents by confiscating the term 'humanity. ${ }^{72}$ Schmitt warned for its dehumanizing consequences:

'to confiscate the word humanity, to invoke and monopolize such a term, all this could only reveal the terrible pretense, as one cannot carry such an exalted name without certain consequences, that the enemy is denied the quality of being human, that he is declared hors-la-loi and hors-la-humanité, and that therefore the war should be driven to its most extreme inhumanity. ${ }^{73}$

As Schmitt suggested, wars waged in the name of humanity ran the risk of degenerating into legally unrestrained killing campaigns: as the enemy was denied his quality of being human, the only option that seemed to remain was his total extermination from the earth. In a footnote, Schmitt referred to Francis Bacon's assertion that the American Indians were 'proscribed by nature,' because they practiced cannibalism. ${ }^{74}$ As Schmitt observed, the designation of the Indians as 'enemies of all humanity' had effectively sealed their fate: 'the Indians of North America were then also effectively exterminated [die Indianer Nordamerikas sind denn auch wirklich ausgerottet worden]. ${ }^{75}$ Schmitt concluded that, from a political

71 For instance, according to the Law of 22 Prairial, year II (also known as the 'Law of the Great Terror'), jurors trying 'enemies of the people' were to be guided by their conscience, and the procedure should be dictated by 'good sense,' rather than procedural rules. The accused were denied access to a lawyer. Moreover, in the absence of material proof, they could be convicted on the basis of 'moral evidence,' and witnesses were no longer deemed necessary. Law of 22 Prairial, year II (June 10, 1794), in: John Hall Stewart, A Documentary Survey of the French Revolution (New York: Macmillan, 1951), 528-31.

72 Carl Schmitt, The Concept of the Political, trans. George Schwab, with a foreword by Tracy B. Strong and notes by Leo Strauss (Chicago: University of Chicago Press, 1996), 54.

73 Schmitt, Concept of the Political, 54 (trans. modified).

74 Francis Bacon had argued that the Indians' 'sacrificing, and more especially their eating of men, is such an abomination, as (methinks) a man's face should be a little confused to deny that this custom, joined with the rest, did not make it lawful for the Spaniards to invade their territory, forfeited by the law of nature [per legem naturae proscripta].' Francis Bacon, An Advertisement Touching a Holy War, ed. Laurence Lampert (Indiana University, 2005), 37.

Schmitt, Concept of the Political, 54, n. 3 (trans. modified). 
perspective, the term 'humanity' was a 'very useful ideological instrument': it enabled states to justify their wars of imperialist expansion as 'ethical-humanitarian' causes, even if they resulted in the 'extermination' of entire peoples.

However, in Schmitt's own time, genocide was committed, not in the name of humanity, but in the name of the people. Soon after the National Socialists had taken to power in Germany in January 1933, they seized upon the pretext of the Reichstag fire to declare a state of exception and suspend the rights of citizens. ${ }^{76}$ In the following days, many opponents of the Nazi-regime were arrested. The main suspects were brought to trial for arson and conspiracy, but only after the law had been changed to reintroduce the death penalty for these offenses. Dissatisfied with the outcome of the Reichstag fire trial, in which only one of the accused was convicted, the Nazis created a special tribunal, the 'People's Court [Volksgerichtshof],' designating suspects as 'enemies of the people,' and stripping them of their rights. The 'People's Court' gradually expanded its jurisdiction at the expense of the ordinary courts: as its President Roland Freisler claimed, 'every crime should be considered a gradation of "Volksverrat [treason against the people]". 77 Once again, the logic of exceptionalism threatened to infect the entire legal system, as any crime could potentially be framed as 'treason against the people.' Thus, disregarding the variety of offenses, the People's Court imposed the death penalty for the slightest as well as the most serious of crimes. In the Summer of 1934, Schmitt himself took the initiative of justifying the summary executions of several of Hitler's opponents during the Night of the Long Knives: the 'act of the Führer,' Schmitt asserted, 'was not subject to justice, but was itself the highest form of justice. ${ }^{78}$ As Schmitt maintained, every act of the state or judicial decision could only be lawful to the extent that it was informed by the 'people's right to life [Lebensrecht des Volkes]. ${ }^{79}$ In September 1935, the Nuremberg laws were passed, depriving Jews and anyone suspected of being disloyal to the German people of their citizenship. ${ }^{80}$ A continuous flow of anti-Jewish legislation caused the Jews to be gradually expelled from social life. Dehumanized and deprived of their rights, they were eventually deported to concentration camps, where they were exterminated in gas chambers.

After the war, the main officials responsible for these Nazi-atrocities were tried by an international tribunal at Nuremberg for 'crimes against humanity.' 81 However, perhaps aware of its risks, the tribunal did not invoke the 'enemy of all humanity' concept. By contrast, when Adolf Eichmann was seized by Israeli agents in Argentina and tried in Jerusalem for his role in the Nazi-atrocities, the

76 Verordnung des Reichspräsidenten zum Schutz vom Volk und Staat, February 28, 1933.

77 Freisler quoted in Edelstein, Terror, 269, n. 49.

78 Carl Schmitt, 'Der Führer schützt das Recht' (1934), in Positionen und Begriffe im Kampf mit Weimar - Genf - Versailles, 1923-1939 (Berlin: Duncker und Humblot, 1994), 228-29.

79 Schmitt, 'Der Führer', 229.

80 Reich Citizenship Law of 15 September 1935, Art. 2/1: 'A Reich citizen is a subject of the state who is German or of related blood, and proves by his conduct that he is willing and fit to faithfully serve the German people and Reich.'

81 Charter of the International Military Tribunal, August 8, 1945, Art. 6c. 
Israeli Attorney-General Gideon Hausner did invoke the pirate-analogy to justify Israel's competence to try Eichmann as an 'enemy of all humanity' under the law of nations. ${ }^{82}$ In her report of the Eichmann trial, Hannah Arendt criticized the court for adopting Hausner's pirate-analogy: on her view, it failed to do justice to the specific nature of the crimes Eichmann had committed. As Arendt explained, the reason why states had universal jurisdiction to try pirates was that they committed their crimes on the high seas, that is, on 'no man's land.' More particularly, pirates were 'outlaws,' because they had chosen to place themselves outside all organized communities, and had therefore become the 'enemy of all alike. ${ }^{\text {'83 }} \mathrm{By}$ contrast, Eichmann had neither committed his crimes on 'no man's land,' nor had he placed himself 'outside all organized communities.' Instead, Arendt explained, the 'pirate analogy served only to dodge one of the fundamental problems posed by crimes of this kind, namely that they were, and could only be, committed under a criminal law and by a criminal state. ${ }^{\text {}} 4$ Unlike the pirate's crimes, the Nazi crimes were statist offenses: these crimes had not been committed in a state of anarchy or 'anomic zone,' but it was the fact that the Nazis could dispose of a modern state apparatus and a modern legal system that had made these crimes possible in the first place. On Arendt's view, it was thus characteristic of the Nazi crimes that they had been committed by dutiful civil servants like Eichmann, and that lawyers had prepared the way for these crimes by creating a parallel legal system, using the law to systematically deprive the Jews of their rights.

The concept of the 'enemy of all humanity' was not widely adopted by other courts after the Eichmann trial. Luban found only two other cases in which it served to justify universal jurisdiction for trying international core crime offenders. In 1979, a Paraguayan citizen was sued before a US court for having tortured the seventeen-year-old Joelito Filártiga to death during the Stroessner dictatorship. The US court accepted universal jurisdiction to try the case, observing that 'the torturer has become, like the pirate and the slave trader before him, hostis humani generis, an enemy of all mankind. ' 85 However, as Luban explains, the Filártiga case remained an exception: when plaintiffs began suing multinational corporations for collaborating with criminal regimes, the courts quickly limited the possibilities for recognizing universal jurisdiction in torture cases. ${ }^{86}$ In 2003, a judge of the International Criminal Tribunal for Former Yugoslavia concluded that international core crime 'offenders are perceived as hostis generis humani, because the norms breached by the conduct protect universal values.' This was because of the 'character of the crime as one that by reason of its gravity and scale

83 Hannah Arendt, Eichmann in Jerusalem: A Report on the Banality of Evil (London: Penguin, 1994 [1963]), 262.

84 Arendt, Eichmann, 262.

85 Filártiga v. Peña-Irala, 630 F.2d 876, 890 (2nd Cir. 1980). The case is discussed in Luban, 'Enemy of All Humanity,' 125.

86 Luban, 'Enemy of All Humanity,' 125. 
offends international public order. ${ }^{\prime 87}$ For Luban, the judge's opinion demonstrates that 'the perpetrator of any core crime - not only torture - is a hostis generis humani, because the crime's gravity and scale offend the international public order. ${ }^{\text {} 88}$ However, apart from this judge's opinion, there are no other examples of international tribunals adopting the hostis humani generis concept to justify universal jurisdiction for trying perpetrators of international core crimes. ${ }^{89}$ As Luban explains, today's international tribunals do not need to justify their universal jurisdiction and, therefore, they have no interest in designating core crime offenders as 'enemies of all humanity. ${ }^{90}$ However, as I have suggested, there may also be another explanation why international tribunals have generally refrained from invoking the hostis humani generis concept: as we have seen, in the past, the concept had often been used to establish parallel systems of justice. Rather than protecting the rule of law by bringing 'enemies of all humanity' to justice, it had been abused to deprive political opponents of their rights.

Perhaps this also explains why national governments, rather than international tribunals, are primarily responsible for the most recent revival of the hostis humani generis concept. Thus, in the aftermath of the terrorist attacks of September 11, 2001, the Bush administration started describing terrorists as 'enemies of humanity.' As President Bush explained, '[t]hese militants are not just enemies of America, or the enemies of Iraq, they are the enemies of Islam and they are the enemies of humanity. ${ }^{\text {'91 }}$ Several scholars have defended the Bush administration's identification of terrorists as 'enemies of humanity.' For instance, in a widely discussed paper, Douglas Burgess pointed at parallels between terrorism and piracy, claiming that identifying terrorists as 'enemies of humanity' had 'significant advantages, chief among them the possibility of universal jurisdiction.'92 However, the Bush administration invoked the 'enemy of humanity' concept not only to justify universal jurisdiction, but also to deprive suspected terrorists of their rights. Thus, lawyers of the Bush administration used the pirate-analogy to support their claim that suspected terrorists were not subject to the Geneva Conventions. As John C. Yoo, Deputy Assistant Attorney General, explained: 'Why is it so hard for people to understand that there is a category of behavior not covered by the legal system? What were pirates? They were not fighting on behalf of any nation. What were slave traders? Historically, they were people so bad that they were not given protection of the laws. There were no specific provisions for their trial, or imprisonment. If you were an illegal combatant, you didn't deserve

87 Prosecutor v. Milutinović, Ojdanić, and Sainović, Decision on Motion Challenging Jurisdiction, Case No. IT-99-37-PT, 6 May 2003, separate opinion of Judge Robinson §7. See Luban, 'Enemy of All Humanity,' 125.

88 Luban, 'Enemy of All Humanity,' 125.

89 Luban found one other example, in which the ICTY quotes from the Filártiga case. IT-95-17/1-T, Judgment of 10 December 1998, § 147. See Luban, 'Enemy of All Humanity,' 126, n. 54.

90 Luban, 'Enemy of All Humanity,' 126, n. 54.

91 Speech of George W. Bush, Chrysler Hall, Norfolk Virginia, October 28, 2005, https:// georgewbush-whitehouse.archives.gov/news/releases/2005/10/20051028-1.html.

92 Douglas R. Burgess, 'The Dread Pirate Bin Laden,' Legal Affairs (July/ August 2005), http://www. legalaffairs.org/issues/July-August-2005/feature_burgess_julaug05.msp. 
the protection of the laws of war. ${ }^{93}$ The Bush administration's references to the 'enemy of humanity' concept thus served to create a parallel system of justice, implying that suspected terrorists could be held indefinitely and tried by military commissions. As Edelstein observes, this application of the 'enemy of humanity' concept to suspected terrorists, 'uncannily recall[ed] the French revolutionary use of the concept during the Terror.' 94

\section{Conclusion}

David Luban has recently proposed to revive the age-old concept of the hostis humani generis, the 'enemy of all humanity.' He argues that no other concept 'quite captures the twin nature of atrocity and persecution crimes that makes the idea of international criminal justice imperative, that they are radically evil, and that they are everyone's business. ${ }^{95}$ Although Luban is aware that this concept has been abused in the past to deprive 'enemies of all humanity' of their rights, he also believes that the 'modern motivation to use the label hostis humani generis has been to put radical evil on trial, not to preclude such trials. ${ }^{\text {'96 }}$ Thus, so long as we insist that 'enemies of all humanity' are themselves members of humanity and accountable to humanity, there is no danger that they will be dehumanized or deprived of their rights. ${ }^{97}$ Here I disagree with Luban, notwithstanding the many valuable insights he provides. Contrary to Luban, I believe that even if the 'enemy of all humanity' concept is used with the intention to bring today's perpetrators of 'radical evil' to justice, it risks undermining, rather than protecting, the rule of law. As I have showed in my paper, in the past, the concept has often served to establish parallel systems of justice, depriving 'enemies of all humanity' of their rights as a suspects under criminal law and as lawful combatants under the laws of war. Even if the concept was applied with the motivation to put 'enemies of all humanity' on trial, it led to discourses of exceptionalism that proved difficult to contain (as occurred, for instance, after the trial of Louis XVI, which provided the template for other kinds of hostility, from the hors-la-loi to the 'enemy of the people'). Moreover, I believe that the 'enemy of all humanity' concept has no added value whatsoever: as the case-law of international tribunals suggests, it is very well possible to hold today's perpetrators of atrocity and persecution crimes legally accountable without denouncing them as 'enemies of all humanity.'

More recently, the Bush administration has invoked the 'enemy of all humanity' concept to support its claim that suspected terrorists are not subject to the Geneva Conventions. This has once again led to the creation of a parallel system of justice, implying that suspected terrorists can be detained indefinitely and tried of Humanity: The Nineteenth-Century War on Terror, ed. Isaac Land (New York: Palgrave, 2008), 7.

94 Edelstein, Terror, 272.

95 Luban, 'Enemy of All Humanity,' 134.

96 Luban, 'Enemy of All Humanity,' 133.

97 Luban, 'Enemy of All Humanity,' 136. 
by military commissions. Although the US Supreme Court has ruled that the suspension of habeas corpus is unconstitutional, ${ }^{98}$ suspected terrorists continue to be held at Guantánamo Bay even today. ${ }^{99}$ In view of these developments, I disagree with Luban's proposal to revive the 'enemy of all humanity' concept in the context of international criminal justice. Luban expects this concept to contribute to bringing today's perpetrators of 'radical evil' to justice, provided that we insist that they are 'members of humanity.' 100 However, as I have argued, in the past, the 'enemy of all humanity' concept has mainly served to declare particular enemies beyond the pale of the law: they were denounced as 'monsters' and 'unnatural beings,' who had been 'proscribed by the law of nature.' Hence, it is not realistic to expect that the 'enemy of all humanity' concept will contribute to recognizing today's perpetrators of 'radical evil' as fellow-human beings. Moreover, in spite of Luban's admirable intention to regard these 'enemies of all humanity' as criminals to be dealt with by fair trials and humane punishments (rather than as outlaws or military targets), it risks contributing to a logic of exceptionalism that undermines legal protection. More particularly, it may lead to the creation of a parallel system of justice, depriving 'enemies of all humanity' of their rights as suspects under criminal law and lawful combatants under the laws of war. History shows that, once created, such exceptional categories are difficult to contain. 